\title{
Chemical and Physical Properties of Seawater-Neutralized Bauxite Residue Mud and Sand and the Effects of Leaching
}

\author{
Y. Li, R. J. Haynes, Y.-F. Zhou, and I. Chandrawana
}

\begin{abstract}
Bauxite processing residues (mud and sand) originating from a major source of bauxite being mined and processed for alumina production in Australia were collected and characterized. Mixtures consisting of 0:100, 25:75, 50:50, 75:25 and $100: 0 \% \mathrm{v} / \mathrm{v}$ residue mud: residue sand were incubated for four weeks and a portion was then leached bi-weekly for another 14 weeks. The macroporosity of sand was much greater than that of mud. Adding increasing proportions of sand to mud decreased total porosity and increased macroporosity but the increase was only appreciable with the presence of $75 \%$ sand. The main elements present in residues were $\mathrm{Fe}, \mathrm{Al}$ and $\mathrm{Si}$ and the main crystalline minerals present were hematite, sodalite and goethite. The amorphous component made up 32 to $42 \%$ of the mineral content. Due to seawater neutralization of the residues, they had a high $\mathrm{EC}$ and soluble Na and Ca content. Leaching caused a decrease in the EC of residues by at least one order of magnitude and ammonium acetate-extractable $\mathrm{Na}$ levels were reduced by more than half. The $\mathrm{pH}$ in leachates from residues increased progressively until they were about two units higher than initial values and the $\mathrm{pH}$ of residues also increased. This was attributed to dissolution of solid phase alkalinity present in the residue.
\end{abstract}

Index Terms-Bauxite processing mud, bauxite processing residue, red mud, leaching.

\section{INTRODUCTION}

Australia is the world's largest miner of bauxite and generates about $30 \%$ of the global alumina production [1]. A major bauxite deposit currently being mined and refined in Australia is at Weipa, Queensland. The Weipa deposit is one of the world's highest grade deposits $\left(49-53 \% \mathrm{Al}_{2} \mathrm{O}_{3}\right)$ mined on a commercial scale anywhere in the world. In alumina refineries, the Bayer process is used to extract alumina by dissolving bauxite ore in hot $\mathrm{NaOH}$ [2]. For every tonne of alumina extracted, 1-2 tonnes of alkaline, saline/sodic bauxite processing residues are produced and these are deposited in residue disposal areas surrounding the refinery. At many refineries, the residues are separated into residue sand $(>150 \mathrm{um})$ and residue mud ( $<150 \mathrm{um})$ which are deposited separately.

Manuscript received April 25, 2015; revised June 17, 2015.

Y. Li, R. J. Haynes, and Y.-F. Zhou are with the School of Agriculture and Food Sciences/CRC CARE, the University of Queensland, St Lucia, Queensland 4027, Australia (e-mail: y.li27@uq.edu.au, r.haynes1@uq.edu.au,y.zhou3@uq.edu.au).

I. Chandrawana is with Rio Tinto Alcan, Queensland Research and Development Centre, 1 Technology Court, Pullenvale, Brisbane, QLD 4069 , Australia (e-mail: irena.chandrawana@riotinto.com).
Using the Weipa deposit, Rio Tinto Alcan does not separate the mud from the small amount of sand present but deposit residue, (after seawater neutralization) by semi-dry stacking (30\% solids) between soil-based retaining walls. Seawater neutralization is a process by which the residue is reacted with seawater with the result that some soluble alkalinity $\left(\mathrm{HCO}_{3}{ }^{-} / \mathrm{CO}_{3}{ }^{2-}\right)$ in the residue is precipitated as poorly soluble $\mathrm{Ca}$ and $\mathrm{Mg}$ hydroxides and hydroxycarbonates. By this process the $\mathrm{pH}$ of the residues is reduced from 11-13 down to about 9 [3].

Before revegetation of residue mud, residue sand is commonly added in order to improve aeration, drainage and root penetration [4], [5]. The purpose of this study was to investigate the chemical and physical properties of seawater neutralized residues and evaluate the effect of adding residue sand to mud on soil chemical and physical properties of the substrate. The combinations used were: $100 \%$ mud, $75 \%$ $\mathrm{mud} / 25 \%$ sand, $50 \% \mathrm{mud} / 50 \%$ sand, $25 \% \mathrm{mud} / 75 \%$ sand and $100 \%$ sand.

\section{Methodology}

\section{A. Samples and Experiment Design}

Bauxite residues were obtained from a Rio Tinto alumina refinery in northern Queensland (derived from Weipa bauxite). The mud and sand were collected immediately following seawater neutralization and prior to their deposition in the residue disposal area. The sand made up approximately $3 \%$ of the total residue mass. Sieve analysis showed that particle size distribution of the residue sand was: $>1 \mathrm{~mm}, 2.3 \%$; $0.5-1 \mathrm{~mm}, 17.6 \%$; $0.25-0.5 \mathrm{~mm}, 43.8 \%$; $0.125-0.5 \mathrm{~mm}, 34.4 \% ;<0.125 \mathrm{~mm}, 1.9 \%$. \%.

For each residue source, five treatments were prepared consisting $0: 100,25: 75,50: 50,75: 25$ or $100: 0 \% \mathrm{v} / \mathrm{v}$ residue mud: residue sand. Samples (1kg dry weight) were thoroughly mixed, rewetted to $70 \%$ water holding capacity and incubated for four weeks in a randomized block design with three replicates. A subsample was air-dried for subsequent chemical analysis while part of the moist sample was used for measurement of physical parameters and another $\left(200 \mathrm{~cm}^{3}\right)$ was transferred to polypropylene leaching tubes (12 cm long and $5 \mathrm{~cm}$ diameter). A plug of glass wool was placed at both the top and bottom of the incubation column to prevent loss of material by downward movement of fine particles during leaching. Samples were incubated for two weeks and then leached slowly (over a 24 hour period) with one pore volume of distilled water. Leachate was collected in polypropylene collecting containers and stored at 
$5{ }^{\circ} \mathrm{C}$ until analysed. Following leaching, a tension of $17 \mathrm{kPa}$ was applied to each column for 10 minutes to remove excess water. This process was repeated every 2 weeks for 7 leachings. At the completion of leaching, residue was removed from tubes and air-dried for subsequent chemical analysis.

\section{B. Chemical Analysis}

In order to determine their mineralogy, residues were subjected to X-ray diffraction analysis. Amorphous content was calculated by difference using a corundum internal standard of known amorphous content. Exchangeable bases $\left(\mathrm{Ca}^{2+}, \mathrm{K}^{+}, \mathrm{Mg}^{2+}, \mathrm{Na}^{+}\right)$were extracted with $1 \mathrm{M}$ ammonium acetate ( $\mathrm{pH}$ 7.0) [6] and analysed by inductively coupled plasma-atomic emission spectroscopy (ICP-AES). EC and $\mathrm{pH}$ were analysed in a 1:5 w/v water extract using a $\mathrm{pH} /$ conductivity meter [6]. Saturated paste extracts were prepared and extracted under vacuum. $\mathrm{pH}$ and $\mathrm{EC}$ in extracts were measured using a glass electrode and $\mathrm{Ca}, \mathrm{Mg}, \mathrm{K}, \mathrm{Na}$ and $\mathrm{Al}$ by ICP-AES. For unleached samples, exchangeable $\mathrm{Ca}$, $\mathrm{Mg}, \mathrm{K}$ and $\mathrm{Na}$ concentrations were calculated by subtracting the concentrations in saturated paste extracts from those in the ammonium acetate extracts [7]. Effective cation exchange capacity was calculated as the sum of exchangeable cations (Ca, Mg, $\mathrm{K}$ and $\mathrm{Na}$ ). Exchangeable sodium percentage (ESP) was calculated as the percentage of exchangeable bases present as $\mathrm{Na}$. Diethylenetriminepentaacetic acid (DTPA)-extractable metals were extracted according to Lindsay and Norvell [8] (0.005 M DTPA, $0.01 \mathrm{M} \mathrm{CaCl}_{2}$ and $0.1 \mathrm{M}$ TEA: 1:2 ratio for $2 \mathrm{~h}$ ) and $\mathrm{Zn}, \mathrm{Cu}, \mathrm{Mn}$, and Fe were analysed by ICP-MS.

The total content of $\mathrm{P}, \mathrm{K}, \mathrm{Ca}, \mathrm{Mg}, \mathrm{Si}$ and heavy metals in residue mud and sand was determined by ICP-AES after microwave digestion using $\mathrm{HF}, \mathrm{HCl}$ and $\mathrm{HNO}_{3}$. Total $\mathrm{C}$ and $\mathrm{N}$ were measured by dry combustion using a Carlo Erba $\mathrm{C}, \mathrm{H}$, $\mathrm{N}$ analyser [6]. In order to calculate the organic $\mathrm{C}$ content of residues, inorganic $\mathrm{C}\left(\mathrm{HCO}_{3}{ }^{-} / \mathrm{CO}_{3}-\mathrm{C}\right)$ was removed from samples by treatment with $1 \mathrm{M} \mathrm{HCl}$ to lower $\mathrm{pH}$ to 4.0 over a 4 day period (with intermittent vigorous mixing). Residual acid was neutralized by raising $\mathrm{pH}$ to 5.0 using $0.5 \mathrm{M} \mathrm{NaOH}$ and the samples were dried at $50{ }^{\circ} \mathrm{C}$ before analysis. Leachates were analysed for $\mathrm{Al}, \mathrm{Ca}, \mathrm{K}, \mathrm{Mg}, \mathrm{Na}, \mathrm{P}$ (ICP-AES) and $\mathrm{pH}$ and $\mathrm{EC}$ using a $\mathrm{pH} /$ conductivity meter.

\section{Physical Analysis}

Bulk density was determined on naturally compacted samples, particle density by the pycnometer method [9] and total porosity by difference. Soil water content in samples was determined at -10 and $-1500 \mathrm{kPa}$ using a pressure plate apparatus. Pore size distribution was calculated as macropores $(>29 \mu \mathrm{m}$ diameter, air-filled pores at $-10 \mathrm{kPa})$, mesopores $(0.2-29 \mu \mathrm{m}$ diameter, drained between -10 and $-1500 \mathrm{kPa})$ and micropores $(<0.2 \mu \mathrm{m}$ diameter, water-filled pores at $-1500 \mathrm{kPa})$.

\section{Germination Assay}

A germination assay was carried out (in quadruplet) on residues before and after leaching using filter paper in petri dishes. Five $\mathrm{mL}$ of aqueous extract $(1 / 10 \mathrm{w} / \mathrm{v})$ from residues was added to dishes [10]. Ten seeds of watercress (Lepidium sativum) were placed on filter paper and dishes placed in the dark at $25{ }^{\circ} \mathrm{C}$. The germination percentages with respect to control (distilled water) and root lengths were determined after 5 days. The germination index (GI) was calculated as $G I$ $=\% G \times L e / L c$, where $\% G$ is the percentage of germinated seeds in each extract with respect to control, Le is the mean total root length of the germinated seeds in each extract, and $L c$ is the mean root length of the control [10]. The control GI value is considered as $100 \%$.

\section{E. Statistical Analysis}

The statistical significance of experimental treatments was determined by subjected the data to Analysis of Variance using the Minitab Software Package. Differences were calculated at the 5\% level using Tukey's test.

\section{RESUlTS AND DISCUSSION}

\section{A. Properties of the Residues}

The elemental and mineralogical content of residues is a reflection of the nature of the parent ore, inputs and transformations that occur during the Bayer process plus any subsequent neutralization reactions. The main elements present in the residue mud and sand were Fe (199 and $247 \mathrm{~g}$ $\left.\mathrm{kg}^{-1}\right), \mathrm{Si}\left(74\right.$ and $\left.101 \mathrm{~g} \mathrm{~kg}^{-1}\right), \mathrm{Al}\left(65\right.$ and $\left.54 \mathrm{~g} \mathrm{~kg}^{-1}\right)$ and $\mathrm{Na}(80$ and $57 \mathrm{~g} \mathrm{~kg}^{-1}$ ) respectively and equivalent values for EC were 16.3 and 7.6. The $\mathrm{pH}$ of both mud and sand was 9.3. Grafe et al. [11] reported that the mineralogy of residues typically contains about $70 \%$ crystalline phases and $30 \%$ amorphous materials and in agreement with this, the mud and sand contained 42 and $32 \%$ amorphous material respectively. The main crystalline components in mud and sand were hematite (29 and 34\%), sodalite (11 and 9\%), boehmite (6 and 8\%) and goethite 2 and $4 \%$ ) respectively. The total $\mathrm{C}$ content of mud and sand was 7.4 and 3.8\% respectively and equivalent values for organic $\mathrm{C}$ were 3.1 and $2.2 \%$. Sodalite (also known as desilication product) is a sodium aluminium silicate mineral formed during the Bayer process which contributes to a slow release of $\mathrm{Na}^{+}$and $\mathrm{OH}^{-}$ions from bauxite residues over time during storage [12], [13]. This pool of residual alkalinity present in the residue in significant quantities means that although the residue was seawater neutralized to a $\mathrm{pH}$ of 9.3-9.4 (Table I) compared to 11-13 for un-neutralized residues [11] an increase in $\mathrm{pH}$ and exchangeable $\mathrm{Na}$ is likely to occur in the longer term, during storage.

Seawater neutralization results in the replacement of some of the $\mathrm{Na}^{+}$on exchange sites with $\mathrm{Ca}^{2+}, \mathrm{Mg}^{2+}$ and $\mathrm{K}^{+}$(from the seawater) and a consequent decrease in Na saturation [3]. Nevertheless, $\mathrm{Na}$ was still the main cation present in ammonium acetate and saturation paste extracts (Table II and Table III). During seawater neutralization, fine mud particles $(<5 \mu \mathrm{m}$ dia.) flocculate into larger agglomerates $(80-400 \mu \mathrm{m})$ [3], [14] and the displaced cations, and those originating from the seawater, can accumulate within the agglomerates. For that reason, cation concentrations (particularly $\mathrm{Na}^{+}$and $\mathrm{Ca}^{2+}$ ) and EC in saturation paste extracts were particularly high in the mud (Table III).

Another consequence of seawater neutralization is the precipitation of soluble alkalinity as sparingly soluble $\mathrm{Ca}$ and 
$\mathrm{Mg}$ hydroxides and hydroxycarbonates (e.g. hydrotalcite) and a consequent decrease in $\mathrm{pH}$ [3], [14]. However, X-ray diffraction analysis did not detect crystalline compounds such as hydrotalcite suggesting they are present in non-crystalline form within the significant amorphous mineral content of residues. It is important to note that the alkalinity associated with the newly-precipitated solid phase is still present in the residue and can potentially be released over time as the materials re-dissolve (causing a $\mathrm{pH}$ increase).

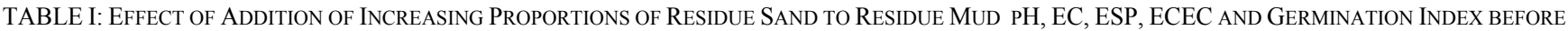
(INITIAL) AND AFTER (FINAL) LEACHING

\begin{tabular}{|c|c|c|c|c|c|c|c|c|c|c|}
\hline \multirow{2}{*}{$\begin{array}{c}\text { Sand addition } \\
(\% \mathrm{v} / \mathrm{v})\end{array}$} & \multicolumn{2}{|c|}{$\mathrm{pH}$} & \multicolumn{2}{|c|}{$\mathrm{EC}\left(\mathrm{dS} \mathrm{m}{ }^{-1}\right)$} & \multicolumn{2}{|c|}{$\operatorname{ESP}(\%)$} & \multicolumn{2}{|c|}{$\operatorname{ECEC~}\left(\mathrm{cmol}_{\mathrm{c}} \mathrm{kg}^{-1}\right)$} & \multicolumn{2}{|c|}{ Germination index $(\%)$} \\
\hline & Initial & Final & initial & Final & Initial & Final & Initial & Final & Initial & Final \\
\hline 0 & $9.4^{\mathrm{a}}$ & $9.9^{\mathrm{a}^{*}}$ & $161^{\mathrm{e}}$ & $1.4^{\mathrm{d}^{*}}$ & $73^{\mathrm{a}}$ & $70^{\mathrm{d}^{*}}$ & $98.6^{\mathrm{e}}$ & $41.0^{\mathrm{a}^{*}}$ & $69^{\mathrm{a}}$ & $75^{\mathrm{a}}$ \\
\hline 25 & $9.3^{\mathrm{a}}$ & $10.0^{\mathrm{a}^{*}}$ & $13^{\mathrm{d}}$ & $1.0^{\mathrm{c}^{*}}$ & $74^{\mathrm{a}}$ & $72^{\mathrm{c}^{*}}$ & $87.6^{\mathrm{d}}$ & $40.2^{\mathrm{a}^{*}}$ & $74^{\mathrm{a}}$ & $68^{\mathrm{a}}$ \\
\hline 50 & $9.3^{\mathrm{a}}$ & $10.2^{\mathrm{a}^{*}}$ & $10^{\mathrm{c}}$ & $0.81^{\mathrm{b}^{*}}$ & $73^{\mathrm{a}}$ & $75^{\mathrm{bc}}$ & $77.5^{\mathrm{c}}$ & $38.6^{\mathrm{a}^{*}}$ & $78^{\mathrm{a}}$ & $72^{\mathrm{a}}$ \\
\hline 75 & $9.4^{\mathrm{a}}$ & $10.3^{\mathrm{a}^{*}}$ & $8.9^{\mathrm{b}}$ & $0.72^{\mathrm{ab} *}$ & $74^{\mathrm{a}}$ & $78^{\mathrm{b}}$ & $68.5^{\mathrm{b}}$ & $38.3^{\mathrm{a}^{*}}$ & $71^{\mathrm{a}}$ & $91^{\mathrm{b}^{*}}$ \\
\hline 100 & $9.4^{\mathrm{a}}$ & $10.5^{\mathrm{a}^{*}}$ & $7.6^{\mathrm{a}}$ & $0.61^{\mathrm{a}^{*}}$ & $75^{\mathrm{a}}$ & $81^{\mathrm{b}}$ & $59.7^{\mathrm{a}}$ & $38.0^{\mathrm{a}^{*}}$ & $71^{\mathrm{a}}$ & $93^{\mathrm{b}^{*}}$ \\
\hline
\end{tabular}

Means followed by same letters within one column are not significantly different at $P \leq 0.05$.

* denotes a significant effect $(P \leq 0.05)$ of measurement time (initial versus final) for that particular property.

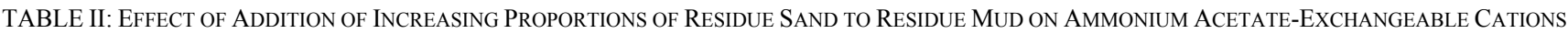
BEFORE (INITIAL) AND AFTER (FINAL) LEACHING

\begin{tabular}{|c|c|c|c|c|c|c|c|c|}
\hline \multirow{2}{*}{$\begin{array}{l}\text { Sand addition } \\
(\% \mathrm{v} / \mathrm{v})\end{array}$} & \multicolumn{2}{|c|}{$\mathrm{Ca}$} & \multicolumn{2}{|c|}{$\mathrm{Mg}$} & \multicolumn{2}{|c|}{$\mathrm{K}$} & \multicolumn{2}{|c|}{$\mathrm{Na}$} \\
\hline & Initial & Final & Initial & Final & Initial & Final & Initial & Final \\
\hline & $19^{\mathrm{d}}$ & $6.3^{\mathrm{b}^{*}}$ & $6.6^{\mathrm{a}}$ & $5.4^{\mathrm{d}^{*}}$ & $1.0^{\mathrm{b}}$ & $0.33^{\mathrm{a}^{*}}$ & $72^{\mathrm{c}}$ & $29^{\mathrm{a}^{*}}$ \\
\hline 25 & $16 f^{\mathrm{fd}}$ & $5.9^{\mathrm{b}^{*}}$ & $6.5^{\mathrm{a}}$ & $5.0^{\mathrm{d}^{*}}$ & $0.99^{\mathrm{b}}$ & $0.34^{\mathrm{a}^{*}}$ & $65^{\mathrm{b}}$ & $29^{\mathrm{a}^{*}}$ \\
\hline 50 & $13^{c}$ & $5.7^{\mathrm{ab}^{*}}$ & $6.6^{\mathrm{a}}$ & $3.6^{\mathrm{c}^{*}}$ & $0.88^{\mathrm{ab}}$ & $0.33^{\mathrm{a}^{*}}$ & $57^{\mathrm{ab}}$ & $29^{\mathrm{a}^{*}}$ \\
\hline 75 & $9.2^{\mathrm{b}}$ & $5.5^{\mathrm{ab}^{*}}$ & $7.5^{\mathrm{b}}$ & $2.4^{\mathrm{b}^{*}}$ & $0.81^{\mathrm{a}}$ & $0.34^{\mathrm{a}^{*}}$ & $51^{\mathrm{a}}$ & $30^{\mathrm{a}^{*}}$ \\
\hline 100 & $6.2^{\mathrm{a}}$ & $4.9^{\mathrm{a}^{*}}$ & $7.7^{\mathrm{b}}$ & $1.8^{\mathrm{a}^{*}}$ & $0.78^{\mathrm{a}}$ & $0.32^{\mathrm{a}^{*}}$ & $45^{\mathrm{a}}$ & $31^{\mathrm{a}^{*}}$ \\
\hline
\end{tabular}

Means followed by same letters within one column are not significantly different at $P \leq 0.05$.

* denotes a significant effect $(P \leq 0.05)$ of measurement time (initial versus final) for that particular property.

The EC values in saturation paste extracts prior to leaching were very high ranging from $28-34 \mathrm{dS} \mathrm{m}^{-1}$ (Table III). Indeed an EC of $>2 \mathrm{dS} \mathrm{m}^{-1}$ is considered saline and values $>12 \mathrm{dS}$ $\mathrm{m}^{-1}$ are generally considered too saline for most plants [15]. Such values underline the importance of allowing time for leaching of salts out of the profile prior to revegetation.

TABLE III: EFFECT OF ADDITION OF INCREASING PROPORTIONS OF RESIDUE SAND to RESIDUE Mud on PH, EC, SAR AND CATIONS IN SATURATED PASTE EXTRACTS

\begin{tabular}{cccccccc}
\hline \multirow{2}{*}{$\begin{array}{c}\text { Sand } \\
\text { addition } \\
(\% \mathrm{v} / \mathrm{v})\end{array}$} & $\mathrm{pH}$ & \multirow{2}{*}{$\begin{array}{c}\mathrm{EC} \\
\left(\mathrm{dS} \mathrm{m}^{-1}\right)\end{array}$} & \multicolumn{5}{c}{ cations $\left(\mathrm{mmol}_{\mathrm{c}} \mathrm{L}^{-1}\right)$} \\
\cline { 5 - 7 } & & & $\mathrm{Ca}$ & $\mathrm{Mg}$ & $\mathrm{K}$ & $\mathrm{Na}$ & SAR \\
\hline 0 & $7.0^{\mathrm{a}}$ & $34.1^{\mathrm{c}}$ & $50.3^{\mathrm{d}}$ & $1.6 \mathrm{a}$ & $7.7^{\mathrm{b}}$ & $698^{\mathrm{c}}$ & $137^{\mathrm{b}}$ \\
25 & $6.8^{\mathrm{a}}$ & $32.3^{\mathrm{bc}}$ & $46.5^{\mathrm{d}}$ & $4.4 \mathrm{ab}$ & $7.5^{\mathrm{b}}$ & $698^{\mathrm{c}}$ & $138^{\mathrm{b}}$ \\
50 & $6.8^{\mathrm{a}}$ & $31.6^{\mathrm{b}}$ & $36.6^{\mathrm{c}}$ & $12.5 \mathrm{~b}$ & $7.0^{\mathrm{ab}}$ & $630^{\mathrm{b}}$ & $127^{\mathrm{b}}$ \\
75 & $6.9^{\mathrm{a}}$ & $30.8 \mathrm{~d}^{\mathrm{ab}}$ & $25.7^{\mathrm{b}}$ & $25.2 \mathrm{c}$ & $6.5^{\mathrm{a}}$ & $588^{\mathrm{ab}}$ & $119^{\mathrm{ab}}$ \\
100 & $6.9^{\mathrm{a}}$ & $28.6^{\mathrm{a}}$ & $9.0^{\mathrm{a}}$ & $44.1 \mathrm{~d}$ & $5.9^{\mathrm{a}}$ & $526^{\mathrm{a}}$ & $102^{\mathrm{a}}$
\end{tabular}

Means followed by same letters within one column are not significantly different at $P \leq 0.05$.

The residues were also sodic as shown by corrected ESP values which ranged from $36-50 \%$ (Table IV) and SAR values of 72-604 (Table III). ESP values above 10-15\% and SAR values above 13 are normally considered likely to reduce plant growth [16]. Even after leaching, ESP values ranged from $67-82 \%$ (Table I). Thus, although tolerance to $\mathrm{Na}$ can differ greatly between plant species, sodicity in all of the residue samples is likely to limit plant performance. A common practice prior to revegetation is to add gypsum $\left(\mathrm{CaSO}_{4} \cdot 2 \mathrm{H}_{2} \mathrm{O}\right)$ to the residue. As well as resulting in some precipitation of alkalinity as calcite, the added $\mathrm{Ca}^{2+}$ displaces exchangeable $\mathrm{Na}^{+}$which leaches down the profile with the added $\mathrm{SO}_{4}{ }^{2-}[17]$. As a result, EC, SAR and ESP are greatly reduced and such a practice would be highly desirable when revegetating these materials.

Critical levels of DTPA-extractable Fe, $\mathrm{Mn}, \mathrm{Zn}$ and $\mathrm{Cu}$ are about $4.5,1.0,0.8$ and $0.2 \mathrm{mg} \mathrm{kg}^{-1}$ [8] so that concentrations of $\mathrm{Fe}, \mathrm{Mn}$ and $\mathrm{Zn}$ were low in residues (Table IV). For revegetation, fertilizer additions of macronutrients (e.g. N, P, $\mathrm{K}$, and $\mathrm{Mg}$ ) as well as $\mathrm{Fe}, \mathrm{Mn}$ and $\mathrm{Cu}$ will be necessary.

TABLE IV: EFFECT OF ADDITION OF INCREASING PROPORTIONS OF RESIDUE SAND TO RESIDUE MUd ON DTPA-EXTRACTABLE METALS AND CORRECTED (Ammonium Acetate Minus Saturation Paste) Exchangeable Na, ECEC AND ESP

\begin{tabular}{|c|c|c|c|c|c|c|c|}
\hline \multirow{2}{*}{$\begin{array}{c}\text { Sand } \\
\text { addition } \\
(\% \mathrm{v} / \mathrm{v})\end{array}$} & \multicolumn{4}{|c|}{$\begin{array}{c}\text { DTPA - extractable metal } \\
\left(\mathrm{mg} \mathrm{kg}^{-1}\right)\end{array}$} & \multirow{2}{*}{$\begin{array}{c}\text { Exchangeable } \\
\mathrm{Na} \\
\left(\mathrm{cmol}_{\mathrm{c}} \mathrm{kg}^{-1}\right)\end{array}$} & \multirow{2}{*}{$\begin{array}{c}\mathrm{ECEC} \\
\left(\mathrm{cmol}_{\mathrm{c}} \mathrm{kg}^{-1}\right)\end{array}$} & \multirow{2}{*}{$\begin{array}{l}\text { ESP } \\
(\%)\end{array}$} \\
\hline & $\mathrm{Fe}$ & $\mathrm{Mn}$ & $\mathrm{Zn}$ & $\mathrm{Cu}$ & & & \\
\hline 0 & $0.41^{\mathrm{a}}$ & 0.00 & & $1.82^{\mathrm{e}}$ & & & 36.7 \\
\hline 25 & $0.49^{\mathrm{a}}$ & $0.68^{\mathrm{ab}}$ & $0.20^{\mathrm{a}}$ & $1.38^{\mathrm{d}}$ & $11.5^{\mathrm{b}}$ & $29.9^{\mathrm{b}}$ & $37.3^{\mathrm{a}}$ \\
\hline 50 & $0.60^{\mathrm{a}}$ & $0.73^{b}$ & $0.23^{\mathrm{a}}$ & $1.05^{\mathrm{c}}$ & $9.2^{\mathrm{a}}$ & $25.2^{\mathrm{a}}$ & $36.5^{\mathrm{a}}$ \\
\hline 75 & $1.14^{\mathrm{a}}$ & $0.88^{\mathrm{c}}$ & $0.20^{\mathrm{a}}$ & $0.57^{\mathrm{b}}$ & $9.6^{\mathrm{a}}$ & $22.9^{\mathrm{a}}$ & $41.6^{\mathrm{a}}$ \\
\hline 100 & $3.16^{\mathrm{b}}$ & $1.28^{\mathrm{d}}$ & $0.25^{\mathrm{a}}$ & $0.21^{\mathrm{a}}$ & $10.0^{\mathrm{ab}}$ & $20.0^{\mathrm{a}}$ & $50.0^{\mathrm{b}}$ \\
\hline
\end{tabular}

Means followed by same letters within one column are not significantly different at $P \leq 0.05$

Calculated ECEC values prior to leaching were reduced greatly when cation concentrations in saturation paste extracts were subtracted (c.f. Table I and Table IV) and this effect was particularly evident for the mud (which had a high $\mathrm{EC}$ and very high concentrations of $\mathrm{Na}$ in saturation paste 
extracts). Corrected ESP values were also lowered because soil solution $\mathrm{Na}$ represented a proportionately greater percentage of the total ammonium acetate-extractable pool than that for other cations such as $\mathrm{Ca}$ and $\mathrm{Mg}$ (since monovalent cations are held less strongly than divalent ones) [18]. After leaching, soluble salts were low and correction of ECEC/ESP was not necessary.

\section{B. Effect of Leaching}

It is likely that the marked increase in $\mathrm{pH}$ of leachates (Fig. 1) and in residues (Table I) during leaching of Weipa residues is due to dissolution of solid phase alkalinity. There are several possible sources of such alkalinity in residues including previously precipitated amorphous hydrotalcite as well as sodalite. Another possible source is tricalcium aluminate hexahydrate (TCA) which is formed when lime is added to Bayer liquor and this also accumulates in the mud [11]. This compound was not found by X-ray diffraction but it is presumed to be present within the amorphous mineral component. A proposed advantage of seawater neutralization is that the $\mathrm{pH}$ of mud is decreased appreciably and this will result in leachates with a lower $\mathrm{pH}$. Such leachates should have much less potential for environmental damage. Work is therefore needed to determine why the $\mathrm{pH}$ of leachates and residues increased during leaching.

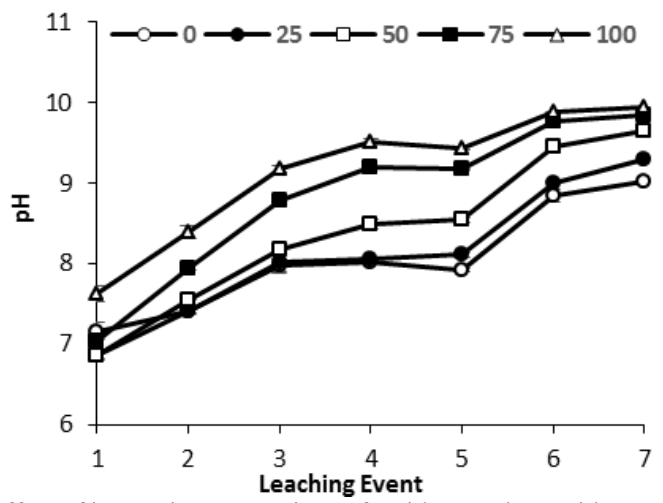

Fig. 1. Effect of increasing proportions of residue sand to residue mud $(0,25$, 50,75 and $100 \%$ ) on $\mathrm{pH}$ of leachates during seven progressive leaching events.

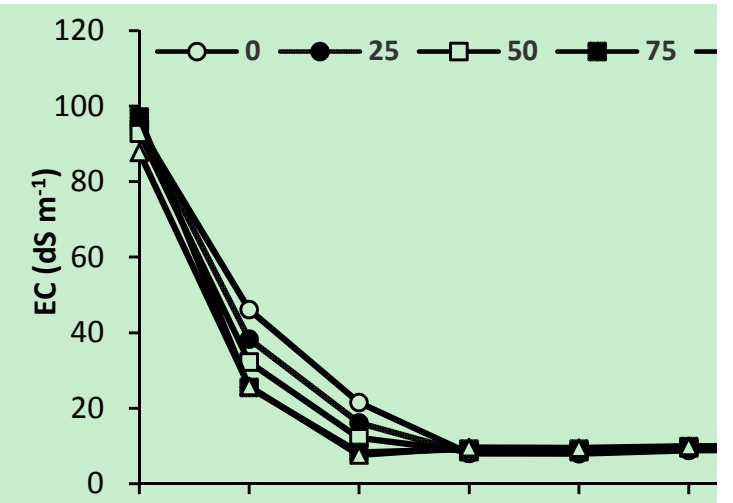

Fig. 2. Effect of increasing proportions of residue sand to residue mud (0, 25, 50,75 and $100 \%$ ) on EC of leachates during seven progressive leaching events.

As shown in Table $\mathrm{V}$, leachate cation content was dominated by $\mathrm{Na}^{+}$and there were only low concentrations of $\mathrm{Ca}^{2+}, \mathrm{Mg}^{2+}$ and $\mathrm{K}^{+}$present. The rapid decrease in EC (Fig. 2) in leachates with time was mirrored in a similar decrease in $\mathrm{Na}$ concentrations (data not shown). This demonstrates that the excess salts in residue mud and sand are readily and rapidly leached out. As already noted, allowing adequate time for leaching is therefore and important management strategy.

TABLE V: EFFECT OF ADDITION OF INCREASING PROPORTIONS OF RESIDUE SAND TO RESIDUE MUD ON MEAN IONIC COMPOSITION OF LEACHATES OVER THE 7-WEEK LEACHING PERIOD

\begin{tabular}{ccccccc} 
Sand $\begin{array}{c}\text { Saddition } \\
(\% \mathrm{v} / \mathrm{v})\end{array}$ & $\mathrm{pH}$ & $\begin{array}{c}\mathrm{EC} \\
\left.(\mathrm{dS} \mathrm{m})^{-1}\right)\end{array}$ & \multicolumn{4}{c}{ Mean concentration $\left(\mathrm{mmol}_{\mathrm{c}} \mathrm{L}^{-1}\right)$} \\
\cline { 4 - 7 } & & & $\mathrm{Na}^{+}$ & $\mathrm{Ca}^{2+}$ & $\mathrm{K}^{+}$ & $\mathrm{Mg}^{2+}$ \\
\hline 0 & $8.1^{\mathrm{a}}$ & $28.0^{\mathrm{a}}$ & $176.0^{\mathrm{d}}$ & $10.5^{\mathrm{b}}$ & $3.7^{\mathrm{a}}$ & $0.4^{\mathrm{a}}$ \\
25 & $8.1^{\mathrm{a}}$ & $26.4^{\mathrm{a}}$ & $154.4^{\mathrm{d}}$ & $8.1^{\mathrm{b}}$ & $3.5^{\mathrm{a}}$ & $1.0^{\mathrm{b}}$ \\
50 & $8.4^{\mathrm{a}}$ & $24.8^{\mathrm{a}}$ & $141.3^{\mathrm{c}}$ & $4.6^{\mathrm{ab}}$ & $3.6^{\mathrm{a}}$ & $1.3^{\mathrm{b}}$ \\
75 & $8.8^{\mathrm{a}}$ & $24.1^{\mathrm{a}}$ & $131.5^{\mathrm{b}}$ & $3.7^{\mathrm{ab}}$ & $3.5^{\mathrm{a}}$ & $2.1^{\mathrm{bc}}$ \\
100 & $9.1^{\mathrm{a}}$ & $22.8^{\mathrm{a}}$ & $112.9^{\mathrm{a}}$ & $1.8^{\mathrm{a}}$ & $3.7^{\mathrm{a}}$ & $4.0^{\mathrm{c}}$
\end{tabular}

Means followed by same letters in one column are not significant difference at $P \leq 0.05$

\section{Physical Properties}

Residue sand had a much greater macroporosity than mud but addition of sand to mud only had a substantial effect on increasing macroporosity when the mixture contained $75 \%$ sand (Table VI). Indeed, additions of small amounts of sand (e.g. 25\%) tended to reduce total porosity and had no significant effect on pore size distribution (Table VI). Additions of sand to mud at $25 \%$ are common practice [5] but results presented here suggest they have little effect on measured physical properties of the medium.

TABLE VI: EFFECT OF ADDITION OF INCREASING PROPORTIONS OF RESIDUE SAND TO RESIDUE MUD ON PHYSICAL PROPERTIES

\begin{tabular}{|c|c|c|c|c|c|}
\hline \multirow{2}{*}{$\begin{array}{c}\text { Sand } \\
\text { addition } \\
(\% \mathrm{v} / \mathrm{v})\end{array}$} & \multirow{2}{*}{$\begin{array}{c}\text { Total } \\
\text { Porosity } \\
\left(\mathrm{m}^{3} \mathrm{~m}^{-3}\right)\end{array}$} & \multicolumn{3}{|c|}{ Pore size distribution (\%) } & \multirow{2}{*}{$\begin{array}{l}\text { Available } \\
\text { Water } \\
\left(\mathrm{kg} \mathrm{m}^{-3}\right)\end{array}$} \\
\hline & & $\begin{array}{l}\text { Micropores } \\
(<0.20 \mu \mathrm{m})\end{array}$ & $\begin{array}{c}\text { Mesopores } \\
(0.20-29 \mu \mathrm{m})\end{array}$ & $\begin{array}{c}\text { Macropore } \\
(>29 \mu \mathrm{m})\end{array}$ & \\
\hline 0 & $0.66^{\mathrm{b}}$ & $34.9^{\mathrm{a}}$ & $65.1^{\mathrm{c}}$ & $0^{\mathrm{a}}$ & $454^{\mathrm{c}}$ \\
\hline 25 & $0.61^{\mathrm{ab}}$ & $36.8^{\mathrm{a}}$ & $63.2^{\mathrm{c}}$ & $0^{\mathrm{a}}$ & $405^{\mathrm{b}}$ \\
\hline 50 & $0.59^{\mathrm{a}}$ & $37.0^{\mathrm{a}}$ & $63.0^{\mathrm{c}}$ & $2.1^{\mathrm{b}}$ & $400^{b}$ \\
\hline 75 & $0.59^{\mathrm{a}}$ & $34.5^{\mathrm{a}}$ & $48.4^{\mathrm{b}}$ & $17.1^{\mathrm{c}}$ & $286^{\mathrm{a}}$ \\
\hline 100 & $0.58^{\mathrm{a}}$ & $35.0^{\mathrm{a}}$ & $40.8^{\mathrm{a}}$ & $24.2^{\mathrm{d}}$ & $238^{\mathrm{a}}$ \\
\hline
\end{tabular}

Means followed by same letters in one column are not significant difference at $P \leq 0.05$.

\section{Germination Index}

Germination was inhibited compared to control (i.e. 100\%) in all treatments to a similar extent before leaching (germination index 69-71\%) but after leaching there was an increase in germination index for $75 \%$ and $100 \%$ sand (Table I). That is, after leaching, there was still significant inhibition of germination in mud (and mixtures containing a substantial amount of mud) and these had greater ESP values than sand. As already noted, a reduction in ESP can be achieved by adding gypsum followed by leaching. Indeed, although germination percentage was satisfactory $(>65 \%)$ in all residues, most plants are unlikely to grow satisfactorily in these materials. Patterns for seed germination versus subsequent growth of plants in bauxite residues are often dissimilar [7] since longer-term physiological effects of salinity/sodicity on plant growth are not assayed in 
short-term germination tests.

\section{E. Practical Implications}

Effectively, it is the mud component which will be revegetated at the Rio Tinto refineries. Although seawater neutralization has lowered $\mathrm{pH}$ to about 9.0 , the salinity is very high and it still has a high $\mathrm{Na}$ content $(>68 \% \mathrm{Na}$ saturation). Displacement of $\mathrm{Na}$ (e.g. with a source of $\mathrm{Ca}$ such as gypsum and/or organic waste) and subsequent leaching of salts will be necessary. The increase in $\mathrm{pH}$ (of both the mud and of leachates) that occurs during leaching of unamended residue needs further investigation. More emphasis needs to be directed towards characterizing the amorphous mineral component of residues particularly with respect to compounds that constitute residual alkalinity.

\section{ACKNOWLEDGEMENTS}

We thank staff of Rio Tinto for collecting the residue samples and Mark Raven of Mineralogical Services of CSIRO, Adelaide, for mineralogical analysis.

\section{REFERRENCES}

[1] Geosciences Australia. (2015). Australian Atlas of Minerals Resources, Minerals Processing Centres. Australian Government, Geosciences Australia. [Online]. Available: http://www.australianminesatlas.gov.au/aimr/commodity/bauxite.html

[2] G. Power, M. Grafe, and C. Klauber, "Bauxite residue issues: I. Current management, disposal and storage practices," Hydrometallurgy, vol. 108, pp. 33-45, 2011.

[3] C. Hanahan, D. McConchie, J. Pohl, R. Creelman, M. Clark, and C. Stocksiek, "Chemistry of seawater neutralization of bauxite refinery residues (red mud)," Environ. Eng. Sci., vol. 21, pp. 125-138, 2004.

[4] R. G. Courtney and J. P. Timpson, "Nutrient status of vegetation grown in alkaline bauxite processing residue amended with gypsum and thermally dried sewage sludge - A two year study," Plant Soil, vol. 266 , pp. 187-194, 2004.

[5] R. G. Courtney, G. Mullen, and T. Harrington, “An evaluation of revegetation success on bauxite residue," Restor. Ecol., vol. 17, pp. 350-358, 2009

[6] G. E. Rayment and F. R. Higginson, Australian Laboratory Handbook of Soil and Water Chemical Methods, Melbourne: Inkata Press, 1992.

[7] B. E. H. Jones, R. J. Haynes, and I. R. Phillips, "Addition of an organic amendment and/or residue mud to bauxite residue sand in order to improve its properties as a growth medium," J. Environ. Manag., vol. 95, pp. 29-38, 2012.

[8] W. L. Lindsay and W. A. Norvell, "Development of a DTPA soil test for zinc, iron, manganese and copper," Soil Sci. Soc. Amer. J., vol. 42, pp. 421-428, 1978.

[9] G. R. Blake and K. H. Hartge, "Particle density," Methods of Soil Analysis, Part 1. Physical and Mineralogical Methods, Second Edition, 1986, pp. 377-382.

[10] O. N. Belyaeva, and R. J. Haynes, "Chemical, microbial and physical properties of manufactured soils produced by co-composting municipal green waste with coal fly ash," Bioresour. Technol., vol. 100, pp. 5203-5209, 2009.

[11] M. Grafe, G Power, and C. Klauber, "Bauxite residue issues: III. Alkalinity and associated chemistry," Hydrometallurgy, vol. 108, pp. 60-79, 2011.
[12] N. J. Barrow, "Possibility of using caustic residue for improving the chemical and physical properties of sandy soils," Aust. J. Agric. Res., vol. 33 , pp. $275-285,1982$.

[13] J. W. C. Wong and G. E. Ho, "Cation-exchange behaviour of bauxite refining residues from Western Australia," J. Environ. Qual., vol. 24, pp. 461-466, 1995.

[14] S. J. Palmer, R. L. Frost, and T. Nguyen, "Hydrotalcites and their role in coordination of anions in Bayer liquors: Anion binding in layered double hydroxides," Coord. Chem. Rev., vol. 253, pp. 250-267, 2009.

[15] R. J. Shaw, "Soil salinity - Electrical conductivity and chloride," Soil Analysis: An Interpretation Manual, CSIRO Publishing, 1999, pp. 129-145.

[16] M. E. Sumner, "Sodic soils: New pespectives," Aust. J. Soil Res., vol. 31, pp. 683-750, 1993.

[17] B. E. H. Jones and R. J. Haynes, "Bauxite processing residue: A critical review of its formation, properties, storage and revegetation," Crit. Rev. Environ. Sci. Technol., vol. 41, pp. 271-315, 2011.

[18] N. C. Brady and R. R. Weil, The Nature and Properties of Soils, Lebanon, Indiana, Prentice Hall, 2007.

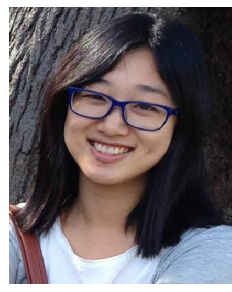

Yaying $\mathbf{L i}$ received her BSc degree in environmental science from Sun Yat-sen University, China, in 2013 She is currently carrying out her $\mathrm{PhD}$ studies at the University of Queensland on revegetation strategies for seawater neutralized bauxite residue mud.

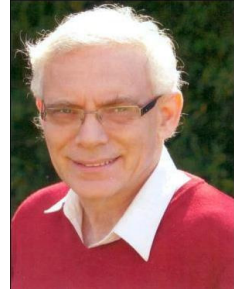

Richard Haynes obtained his BHort Sci, PhD and DSc from Lincoln University, Canterbury, New Zealand. $\mathrm{He}$ is currently a professor of soil and environmental science at the University of Queensland, Brisbane, Australia. He previously worked as a research scientist for the NZ Ministry of Agriculture and Fisheries and the NZ Institute for Crop and Food Research and as a professor of soil science at the University of Natal, South Africa. His research interests center around green and sustainable remediation technologies for bauxite processing wastes from alumina refineries.

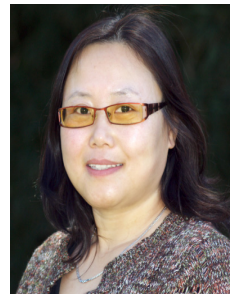

Ya-Feng Zhou obtained her BSc and MSc from Shenyang University of Agriculture majoring in food science. She worked as a research scientist at Wuhan Institute of Virology before moving to Australia in 2007. She received her PhD in environmental science from the University of Queensland in 2011. Since then she has worked as a research scientist at the University of Queensland in the area of sustainable remediation technologies for bauxite processing

wastes from alumina refineries.

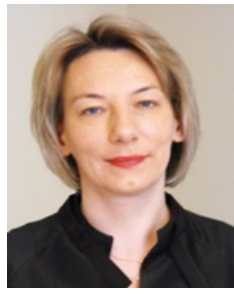

Irena Chandrawana received her $\mathrm{BSc}$ from Murdoch University, Australia, in 2005 majoring in environmental science and chemistry. She worked as a laboratory analyst for Alcoa World Alumina for one year and then for Rio Tinto Alcan as a technical officer, research scientist, analytical program leader and senior research scientist. Since 2013 she has held the position of specialist scientist-residue and environment for Rio Tinto Alcan based in Brisbane. 